\title{
Martí Martínez, C. (2020). Documentación Musical. Barcelona: Editorial UOC (Colección EPI Scholar), 148 pp. ISBN: 978-84-91180-
} 727-8

España posee un patrimonio musical amplio, diverso y de un gran valor cultural, que, sin embargo, hasta épocas bien recientes no ha recibido el tratamiento de conservación y difusión que requería. Sin embargo, el nacimiento de la Asociación Española de Documentación Musical (AEDOM) en 1993 marcó un antes y un después en la contemplación y articulación de los procesos documentales del fenómeno sonoro. Cada día que pasa somos más conscientes de la importancia en la preservación y conocimiento de un patrimonio musical único: piénsese por un momento en el rico legado de los maestros de capilla de catedrales, colegiatas, monasterios, abadías o iglesias parroquiales que atesoraron una cantidad ingente de obras musicales: parte de dicho legado ha sido catalogado y puesto en conocimiento de la comunidad científica pero todavía una parte sustancial permanece inédita.

El libro de Cristina Martí constituye una novedad sin duda excepcional que viene a corroborar la nueva importancia que ha adquirido en los últimos tiempos todos los aspectos relacionados con la documentación musical: la aparición de nuevos centros musicales y la creciente inserción laboral del documentalista musical, cada vez más imprescindible en orquestas, coros, agrupaciones musicales, museos, o centros culturales son claros ejemplos de esta tendencia.

La aportación de Cristina Martí1 está presidida por el rigor metodológico y por la claridad en la exposición de la variedad de aspectos que rodean la labor del documentalista musical, que debe en todo momento adaptarse a muy diferentes problemáticas, que son planteadas de manera diáfana: no es lo mismo enfrentarse a la conservación y catalogación de un libro de facistol gregoriano que al moderno soporte digital. A todas estas cuestiones responde la autora.

\footnotetext{
${ }^{1}$ Cristina Martí es una reconocida autora, responsable desde hace muchos años de un excelente blog titulado "Papeles de Música", ampliamente seguido. Acumula una gran experiencia en el ámbito de la documentación musical pues a su amplia formación en este sentido se añaden sus trabajos en la Biblioteca Nacional de España, la Orquesta y Coro Nacionales de España o la Biblioteca Tomás Navarro Tomás. En la actualidad imparte clases en el Máster en Investigación Musical de UNIR, además de trabajar como documentalista musical en un medio de comunicación.
} 
Tras una completa definición de lo que se entiende por documentación musical, analiza Martí los distintos documentos musicales, diferenciando acertadamente entre documentos musicales con música notada (borradores; partitura de estudio; partitura abreviada; partitura vocal; partitura de coro; parte de apuntar; guión; reducción para piano; partitura o libro de mesa; partes; parte de piano director, violín director, etc.; libro de coro, cantoral o facistol; y ediciones críticas), documentos musicales con música interpretada (grabaciones mecánicas; grabaciones electromagnéticas; y grabaciones digitales y aquellos documentos de interés musical como catálogos temáticos, monografías y textos con ejemplos musicales, manuales, métodos y libros de ejercicios, cancioneros. Otro capítulo, muy necesario, por cierto, está dedicado al patrimonio musical: su definición y qué plantea la actual legislación en torno a este concepto y su protección estatal o autonómica. Por otra parte, el tercer capítulo hace referencia a la localización de los fondos musicales en bibliotecas, archivos, museos y centros de documentación musical, detallando con gran profusión de datos aquellos centros e instituciones que conservan fuentes relacionadas con la documentación musical, lo cual supone para el estudiante y el profesional una notable ayuda en sus labores de investigación; sólo habría que apuntar una omisión en la relación de centros de investigación musical: el Centro de Investigación y Documentación Musical de la Universidad de Castilla-La Mancha, único centro que está reconocido al más alto nivel por el Consejo Superior de Investigaciones Científicas.

De gran interés es asimismo el capítulo consagrado a la labor del documentalista, definiendo con precisión sus competencias y perfiles profesionales. Desde los tiempos en que Barbieri afirmara en 1877 que "para ser bibliotecario musical lo primero y principal que se requiere es ser en absoluto, bibliotecario, y después, conocedor de la música” (pág. 57), la concepción del documentalista musical ha ido evolucionando y sus funciones se han ampliado notablemente a favor de una mayor especialización, pues no es lo mismo, como bien afirma Cristina Martí, trabajar para una Fonoteca musical generalista que para un centro de documentación musical especializado en la zarzuela. Como ejemplo de lo que comentamos, el Comité de Formación Profesional de la Music Library Assocation definía en 1974 qué tipo de competencias y habilidades debía poseer un bibliotecario musical, concretándolas en las siguientes: conocimiento de los materiales; habilidades musicales aplicables a la biblioteca; y como competencia general, la música (música práctica, historia de la música, música popular y etnomusicología). Dado el tiempo transcurrido, a todo ello habría que agregar, según la autora del libro, las competencias en tecnologías informáticas. Alude asimismo Martí al perfil académico necesario para convertirse en documentalista musical y a las salidas profesionales.

El quinto capítulo aborda un aspecto esencial de la documentación musical: las diferentes tipologías de fuentes musicales, como catálogos temáticos, bibliografías y bases de datos bibliográficas, catálogos discográficos, guías, biografías y necrologías, enciclopedias y diccionarios, acceso a documentos primarios, publicaciones periódicas, bases de datos, directorios, buscadores y la web 2.0.

Por último, en el sexto capítulo, la autora del libro se centra en la descripción de los documentos musicales, aludiendo a sus normas, reglas y estándares, todo explicado con gran acopio de datos y precisión. 


\section{RESEÑAS DE LIBROS}

En definitiva, nos encontramos ante una publicación de gran valor y muy recomendable, cuya lectura es indispensable para cualquier persona que trabaje en el ámbito de la música al tratarse de una de las primeras monografías que intenta compendiar, con éxito, los aspectos que rodean a la documentación musical de forma integral. Nuestra enhorabuena para la autora y para la editorial de la Universidad Oberta de Cataluña por esta novedad tan significativa, que, como decíamos al principio de esta reseña, constata la importancia creciente que está desempeñando la preservación de nuestro rico patrimonio musical.

\section{Paulino Capdepón Verdú}

Universidad de Castilla-La Mancha Centro de Investigación y Documentación Musical (CIDoM)-Unidad Asociada al CSIC ORCID iD: https://orcid.org/0000-0001-6509-3496 